\title{
Pouke iz rane Crkve za današnje evanđeosko kršćanstvo
}

\author{
Ervin Budiselić \\ Biblijski institut, Zagreb \\ ebudiselic@bizg.hr
}

UDK:27-27;27-72;279

Izvorni znanstveni članak

Primljeno: 1, 2017.

Prihvaćeno: 3, 2017

\section{Sažetak}

Pretpostavljajući da u evanđeoskom kršćanstvu postoji kriza biblijskog tumačenja, ovaj članak nastoji ukazati na tu problematiku, posebice zato što je za evanđeosko kršćanstvo postojanje Crkve usko vezano uz navještaj Istine. Polazeći od pozicije da evanđeoska hermeneutika nije rođena u vakuumu, već je rezultat povijesnog procesa, u prvome dijelu članka uvodno se analizira problematika između sola $i$ solo scripture, $i$ ističu se neka problematična pitanja na koja treba obratiti pozornost. $U$ drugome dijelu članak se bavi hermeneutikom u partističkom razdoblju, posebice: a) odnosom između Pisma i tradicije, koje je utjelovljeno u pravilu vjere (regula fidei); b) teološkim pretpostavkama koje su dovele do alegorijskog i doslovnog tumačenja Pisma u Aleksandriji i Antiohiji. U zadnjem dijelu članka, na osnovu nekih lekcija iz patristike, predlaže se revizija prakse tumačenja Pisma među evanđeoskim kršćanima. Naročito, evanđeoski kršćani trebali bi: $i$ dalje smatrati Bibliju jedinim nepogrešivim izvorom kršćanske doktrine, nastaviti razvijati povijesno-gramatičku metodu, posebice u odnosu na pitanje analogije vjere u egzegetskom procesu, ali jednako tako bi trebali prepoznati da Biblija ne može u cijelosti imati ulogu pravila vjere ili analogije vjere. Ovome svemu mora se pridružiti još nešto, a to nešto drugo bi trebalo biti otkrivanje patritičkog razdoblja kao „jedne vrste doktrinarnog kanona“.

Ključne riječi: hermeneutika, pravilo vjere, evanđeosko kršćanstvo, patrističko razdoblje, tradicija, sola scriptura, solo scriptura. 


\section{Uvod}

Evanđeosko kršćanstvo u velikoj mjeri vuče svoj identitet iz reformacije. Zbog svoga isticanja Svetog pisma, evanđeosko kršćanstvo često ima nepovoljan stav o povijesti kršćanske Crkve. Protestantske crkve iz doba reformacije priznavale su da istinska kršćanska crkva postoji, samo što je treba reformirati. Takvo stajalište nosi pozitivniji pristup i spremno je učiti iz povijesti, jer Crkva nikad nije prestala postojati. Radikalnija je grana reformacije držala stajalište da je Crkva u nekom trenutku povijesti prestala postojati. Zbog toga ju je trebalo ponovno stvoriti. To znači da je tek pojavom određene crkvene skupine, pokreta i denominacije nekako došlo do ponovnog nastanka "istinske kršćanske crkve". Međutim, koji čimbenik određuje postojanje, odnosno prestanak postojanja Crkve?

Među evanđeoskim vjernicima tradicionalno se smatra da istinska Crkva postoji ondje gdje se propovijeda o Bogu. Međutim, ne možemo prosuđivati o tome "čini" li ova ili ona skupina vjernika Crkvu dok ne utvrdimo precizna pravila kojima ćemo definirati ispravno učenje i tumačenje Pisma. ${ }^{1}$ Ako prihvatimo tvrdnju da je protestantizam, a još više evanđeosko kršćanstvo, suočeno s krizom biblijskog tumačenja, onda je riječ o egzistencijalnom pitanju, i to s pravom, jer je pravilna hermeneutika usko vezana uz pitanje postojanja Crkve. Koji je ispravan pristup ovome problemu? Ako prihvatimo radikalan pogled na povijest Crkve, koji pretpostavlja da je "moja skupina" krenula od nule i da povijesni događaji ne igraju nikakvu važnu ulogu u "mojoj hermeneutici", onda zatvaramo vrata pred rješenjem ove krize tumačenja. Međutim, ako prihvatimo pozitivan pogled na povijest Crkve, postoji šansa da ćemo proučavanjem povijesnih događaja u kontekstu hermeneutike bolje shvatiti trenutačnu situaciju i, potencijalno, doći do nekih rješenja. Ako ništa drugo, naučit ćemo pokoju vrijednu lekciju iz prošlosti.

U ovome ćemo se članku držati savjeta Paula Hartoga $(2007,84)$, koji tvrdi da "suvremena crkva, poput zahtjevnog pacijenta, može ponizno primiti brojne zdrave recepte iz ruke patrističkih liječnika". Ako primijenimo savjet u sadašnjem evanđeoskom svijetu, možemo promatrati kako nas patristička egzegeza može informirati i educirati u trenutnoj krizi evanđeoskog tumačenja Pisma.

Da bih se pozabavio tim pitanjem, u prvome ću dijelu iznijeti uvod u problematiku sole i solo scripture među evanđeoskim kršćanima, ističući izvjesna problematična pitanja koja se trebaju riješiti. U drugom ću dijelu diskutirati o nekim aspektima patrističke hermeneutike, kao što su: a) odnos između Pisma i predaje, koji je utjelovljen u regula fidei; b) teološke pretpostavke koje su dovele do nastanka alegorijskog i doslovnog tumačenja Pisma u Aleksandriji i Antiohi-

1 Svjestan sam da se ovakvo razmišljanje doima čudnim (blago rečeno) tradicionalnijim crkvama, kao što su rimokatolička i pravoslavna, ali pišem članak iz evanđeoske perspektive. 
ji. I konačno, predložit ću izvjesne revizije evanđeoske prakse tumačenja Pisma temeljenih na poukama iz patrističke ere. Kao što ćemo vidjeti, ne samo da je patristička era bila oblikovana svojim naslijeđem nego se i razvijala usred procesa konflikta i debate s raznim frakcijama i herezama. Želio bih pokazati kako je za današnje evanđeoske kršćane osobito važno da budu svjesni ovih povijesnih događaja jer uspjesi i promašaji prošlosti mogu nam pomoći u situaciji u kakvoj se danas nalazi evanđeoska hermeneutika.

\section{Današnja problematika evanđeoskog tumačenja Pisma: sola scriptu- ra, solo scriptura i pravilo vjere}

\subsection{Problem tumačenja}

Evanđeosko je kršćanstvo izgrađeno na naslijeđu reformacije i protestantizma, čiji je glavni pogonitelj bilo načelo sola scriptura. ${ }^{2}$ Sola scriptura nije podrazumijevala odbacivanje crkvenih predaja, nego je tvrdila da se predaja može prihvatiti ako se može opravdati Pismom. U tome smislu, sola scriptura nije hermeneutičko načelo, odnosno načelo tumačenja, nego teološko stajalište koje ističe prvenstvo Svetog pisma. Iako evanđeoski kršćani kategorično inzistiraju na prvenstvu Pisma, važno je istaknuti dvije stvari:

a) Sola scriptura ne podupire ideju da svaka osoba može sama po sebi donijeti kvalitetno i sveobuhvatno tumačenje. Iako su reformatori isprva bili optimistični u pogledu svog vjerovanja da obični vjernik može čitati i razumjeti Pismo, neslaganja između Luthera i Zwinglija pokazala su da jasnoća Pisma nije očita uvijek i u svakome aspektu. Stoga, iako svaki vjernik ima pravo tumačiti Pismo, kod teških i nejasnih odjeljaka reformatori su nudili dva rješenja: a) katekizam, odnosno knjige uputa koje su služile kao filteri pomoću kojih pojedinci mogu tumačiti Pismo; b) političku hermeneutiku, gdje bi gradska vijeća povremeno pružala autoritativna teološka tumačenja i doktrine. Tako su reformatori samo zamijenili autoritet crkvene predaje autoritetom sekularnih vlasti.

b) Sola scriptura ne rješava problem autoritativnog tumačenja Biblije. Jedno je reći da je Biblija jedini nepogrešivi izvor i standard kršćanske doktrine, ali drugo je znati točno o čemu uči taj autoritet. Alister McGrath $(2001,157)$ je bio na dobrom tragu rekavši: "Tekstove treba tumačiti. Nema smisla tretirati neki tekst kao autoritativan ili normativan ako postoje ozbiljna neslaganja glede njegova značenja." Nažalost, u svojim nastojanjima da reformiraju ili ponovno stvore ispravnu

2 Sola scriptura je načelo koje tvrdi da je Sveto pismo / Biblija jedini nepogrešivi izvor i standard kršćanske doktrine, vjere i života te u tom smislu stoji iznad autoriteta pape, koncila i ljudskih mišljenja. Svi drugi autoriteti moraju se podrediti Pismu. 
i čistu doktrinu, diskutabilno je u kojoj mjeri su protestantske i evanđeoske crkve do danas bile uspješne u pružanju autoritativnih tumačenja Biblije.

\subsection{Od problema prema rješenju}

Iako je sola scriptura često optuživana za promicanje subjektivnih i individualističkih tumačenja Biblije, stvarni problem u evanđeoskom kršćanstvu, prema mišljenju Keitha Mathisona (2001, 238), nije sola, nego solo scriptura: "Moderna evanđeoska verzija solo scripture nije ništa drugo doli nova verzija Nulte predaje. Umjesto da se Bibliju definira kao jedini nepogrešivi autoritet, tvrdi se da je ona 'jedini izvor autoriteta' Za predaju nema mjesta ni u kojem smislu, ekumenska kreda se odbacuju, a Crkvi se niječe bilo kakav stvarni autoritet." Drugim riječima, solo scriptura je teološko stajalište prema kojem svaki pojedinac ima pravo tumačiti Bibliju prema svojoj želji. Individualna automonija jako se cijeni, a takvo stajalište često dovodi do kršćanstva tipa "Isus, Biblija i ja". Nasuprot tomu, sola scriptura prihvaća koncept predaje u biblijskom tumačenju, međutim, odnos između Biblije i tradicije u hermeneutici nije uvijek jasno definiran. Moguće ponuđeno rješenje za ovu hermeneutičku zagonetku je dvojako: rješenje leži u primjeni regule fide $i$ i / ili analogiji vjere, koji predstavljaju kontrolni mehanizam tumačenja Biblije, međutim, točna je narav ovoga rješenja jednako diskutabilna. Evo dva moguća pristupa: a) Biblija $i$ pravilo vjere; b) Biblija jest pravilo vjere.

\subsubsection{Biblija i pravilo vjere}

Teolozi poput Keitha A. Mathisona i Craiga D. Allerta sugeriraju da, iako Pismo jest najviši autoritet kršćanske doktrine, života, vjere i prakse, mora ga se tumačiti u skladu s regulom fidei, koja dolazi iz crkvene predaje. Prirodno, ovo stajalište pretpostavlja da se ni Crkva ni regula fidei nisu smatrale drugim dodatnim izvorima otkrivenja (usp. Mathison 2007, 2). Mathison $(2001,151,275)$ smatra da ranoj Crkvi nije bio problem smatrati Pismo i predaju jedinim izvorom Božjeg otkrivenja. Predajom su se smatrali sadržaji doktrina koje je Krist predao svojoj Crkvi, bilo u usmenoj ili pisanoj formi. Apostolska predaja postupno se zapisivala $\mathrm{u}$ dokumente koji danas čine kanon Novog zavjeta, a te se dokumente tumačilo u hermeneutskom kontekstu pravila vjere. Međutim, važno je razumjeti da u ranoj Crkvi nije bilo konflikta između predaje i Pisma jer je njihov sadržaj bio istovjetan. Allet $(2004,344)$ također govori protiv uvriježenoga evanđeoskog stajališta, koje zvuči otprilike ovako:

Rečeno nam je da Biblija mora biti samopotvrđujuće, objektivno i konačno otkrivenje, jer ima 'grešnih ljudi' koji neprestano izokreću Božju riječ. I opet, opažamo da postoje ispravna i neispravna tumačenja Biblije. Jedini način da doznamo koja su ispravna, a koja neispravna jest pozvati se na pravilo vjere - Bibliju. 
Allert $(2004,345)$ smatra da smo tada u nemogućoj situaciji, gdje idemo ukrug, budući da je Biblija u isti mah i predmet i procjenitelj tumačenja. Navodeći Tertulijana kao primjer, Allert tvrdi da u njegovu slučaju korištenje pravila vjere ne ukazuje na to da je istovjetan s Biblijom jer se u diskusiji protiv heretika "poziva na predaju ispravne doktrine koju je Krist donio, apostoli proširili, a konačno ju je pohranila i čuva je apostolska Crkva. Ovakva je predaja ispravne doktrine bila pravilo, odnosno standard za ispravno vjerovanje. Za Tertulijana je pravilo vjere, a ne sama Biblija, bio vodič ispravnoga tumačenja Biblije."

\subsubsection{Biblija jest pravilo vjere}

Drugi evanđeoski teolozi odbacuju ideju da pravilo vjere ima veze s predajom i svode ga na Bibliju. Prema ovome gledištu, Biblija treba biti naš jedini pravilo vjere jer se predaja s vremenom iskvarila. Razmotrimo njihove argumente.

Govoreći o povijesnom razvoju kodeksa vjere, H. Wayne Johnson (1988, 6970) objašnjava da se tijekom povijesti pravilo vjere prije svega definirao kao vjera koju je ispovijedala apostolska Crkva i sveukupnost biblijskog nauka. Nakon toga, pravilo je postalo eklezijastični mehanizam za kontroliranje egzegeze i jamstvo harmonizacije $s$ katoličkim pravovjerjem. Prilikom reformacije pravilo vjere definirao se kao sveukupnost nauka same Bibilje, što je značilo da egzegezu treba primjenjivati u skladu s ostatkom Pisma, a ne u skladu s katoličkom ortodoksijom. Zbog povezanosti pravila vjere s katoličkom zlouporabom, neki evanđeoski kršćani radije se služe pojmom "analogija Pismu".

Uz Johnsona, Joseph F. Mitros (1968, 452-465) analizira razvoj koncepta "predaje". Za Irineja i Tertulijana, predaja je u prvom redu bila izvorna poruka, odnosno apostolski nauk, ali su se služili tim pojmom misleći na nepisana vjerovanja i doktrine, za razliku od Pisma, koje su nazivali kanonom istine i "pravilom vjere". To je bilo moguće zato što su gledali na Pismo kao na dva načina prenošenja istoga izvornog otkrivenja i apostolske predaje. Nadalje, od 3. stoljeća nadalje koncept predaje poprimio je drukčije značenje i počeo je obuhvaćati sveukupnost eklezijastičnog života, poput liturgije, vjerovanja, katehetskih pouka, odluka sinoda i koncila itd. Mitros također tvrdi da je u 3. stoljeću došlo do pojave koncepta čiste usmene, odnosno izvanbiblijske predaje, koja je donosila informacije koje se nisu nalazile u Bibliji. Međutim, ovakvo shvaćanje predaje uglavnom se odnosilo na drevne običaje i obrede, a ne na doktrine, barem ne izravno. Na koncu, Mitros (1968, 467-469) ističe kako u ranoj Crkvi nalazimo još jedan vid predaje, koji je navodno donosio tajnu izvanbiblijsku predaju o ezoteričnim učenjima, koja su navodno došla od Krista s predstavnicima poput Klimenta Aleksandrijskog i Bazilija. Ovakvo proširivanje predaje, koje je bilo otvoreno i dopuštalo je pojavu novih otkrivenja, potkraj srednjeg vijeka dovelo je do divinizacije papinstva. On smatra takav razvoj predaje rezultatom ponovnog uvođenja sensus pleniora - dubljega duhovnog shvaćanja iznimno subjektivne i arbitrarne metode alek- 
sandrijske škole glede egzegeze, što je dovelo veliki nered u kršćansku biblijsku teologiju.

Na temelju ovakvog pogleda na predaju i pogleda na Bibliju, John H. Armstrong ističe:

Protestantski apologeti su tijekom povijesti bili brzi u reagiranju na to inzistirajući da je Pismo dostatno kao canon et regula fidei (tj. kanon i pravilo vjere) jer pravilo koje je nedostatno, nepotpuno i nedovršeno zapravo i nije pravilo... Jedino uz vrhovni, konačni i dostatni autoritet Crkva može imati nešto pouzdano, dosljedno unutar sebe i nikad prijevarno. Takav autoritet mora se nalaziti u samom Pismu.

Philip Schaff $(2007,7)$ zagovara isto pišući da je u protestantskom sustavu autoritet simbola, kao i svih ljudskih tvorevina, relativan i ograničen stoga mora biti podređen Bibliji, koju naziva "jedinim nepogrešivim pravilom kršćanske vjere i prakse". Shodno tomu, "Biblija je od Boga; ispovijedanje je čovjekov odgovor na Božju riječ. Biblija je norma normans; ispovijedi su norma normata. Biblija je pravilo vjere (regula fidei); ispovijedi su pravilo doktrine (regula doctrino)."

Walter Kaiser $(1990,4)$ tvrdi da "je malo teoloških koncepcija bilo konfuznije $\mathrm{i}$ lišenije jasnog razvoja tijekom povijesti Crkve poput ove koncepcije i povezanih

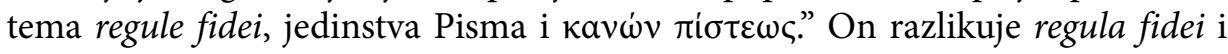
protestantsku uporabu analogije vjere govoreći da:

izraz 'analogija vjere’ nije uvriježen niti se često odnosio na načelo u patrističkoj i srednjovjekovnoj literaturi. Zapravo, javlja se pod brojnim imenima: vjera, katolička vjera, pravilo istine, propovijedanje, [red] predaje, mjera vjere, pa čak i apostolska eklezijastička ili drevna ustanova Crkve (Kaiser 1990, 6).

Nadalje, dodaje da je za reformacije među reformatorima postojala tendencija prema uzdizanju subjektivnih teoloških preferencija, pa čak i crkvene dogme, kao vrhovne norme iznad onoga što govori Pismo. Međutim, $u$ teoriji se vjerovanja Crkve i članci vjere trebaju nalaziti i temeljiti samo na Pismu (usp. Kaiser 1990, 7). Dakle, za njega analogija vjere nije stavljanje vlastita teološkog sustava, ispovijedi i doktrine iznad Pisma jer bi takvo rezoniranje bilo kružno. Riječ je o hermeneutskom načelu koje smatra da Pismo nije podložno bilo kakvom apsolutnom i izvanjskom standardu prema kojem će se mjeriti; drugim riječima, ono je bilo mehanizam koji nije davao (iskvarenoj) predaji pravo da tumači Pismo (usp. Kaiser 1985, 69). U praksi, znači da analogija vjere funkcionira pod pretpostavkom da Pismo tumači Pismo, naime da se nejasni tekstovi i odjeljci moraju tumačiti pomoću drugih tekstova u Pismu, čije je značenje jasnije (usp. Demarest B. 2001, 58) jer se time pretpostavlja da Pismo nije u svakom segmentu izrečeno jednakom jasnoćom (usp. Kaiser 1982, 173). Kaiser $(1990,10)$ je svjestan da razne protestantske skupine imaju svoje analogije vjere (kalvinisti, arminijani, dispenzacionalisti, teolozi zavjeta, karizmatici, cesacionisti) te da čak imaju i vla- 
stito shvaćanje toga koji su tekstovi jasni, a koji nisu. Međutim, važno je shvatiti da regula fidei zapravo jest analogija vjere (usp. Kaiser 1985, 69), tako "Pismo, a ne vjeroispovijedi i doktrinalne tvrdnje, postavlja norme” (Kaiser 1990, 13).

U zaključku možemo reći da Kaiser epitomizira one suvremene evanđeoske kršćane koji tvrde da jedino pomoću Pisma možemo odrediti koje je njegovo tumačenje valjano, tvrdeći da će nas ispravna egzegetska metoda ${ }^{3}$, a ne nekakva tradicija, dovesti do ispravne teologije. Štoviše, zagovara "analogiju prethodnoga Pisma" u kojem nas "raniji navodi, aluzije, iste osobe i događaji 'informiraju' i donose nam kontekst unutar kojeg se čula ova nova Božja riječ” (Kaiser 1990, 13). Dakle, ako su regula fidei ili analogija vjere egzegetska metoda, kao što to Kaiser sugerira, moramo se zapitati koja je točna uloga analogije vjere u egzegetskoj metodi. Zato danas u evanđeoskoj hermeneutici postoji stalna borba za defniniranjem odnosa između analogije vjere i egzegetske metodologije, te prepoznajemo četiri egzegetska obrasca: a) "analogija vjere diktira egzegezu", što znači da onda definira upotrebu egzegetskih metoda, i ako su rezultati egzegeze protivni analogiji, egzegetska metoda mora se mijenjati; b) "analogija vjere je zamjena za egzegezu", gdje je sva egzegeza nevažna ako je njezin rezultat proturječan ortodoksnoj analogiji vjere; c) "analogija vjere kao posljedica egzegeze", gdje se korištenje analogije odgađa do dovršetka egzegetskog procesa; d) "analogija vjere kao jedan od elemenata egzegeze", gdje smo pristupili tekstu s izvjesnim pretpostavkama, koje su se tijekom egzegetskog procesa potvrdile, odnosno izmijenile (usp. Johnson 1988, 70-80).

\section{Patristička egzegeza u kontekstu hereze}

Jeffrey W. Hargis $(1999,1)$ primjećuje sljedeće: “činjenica da je kršćanstvo nastalo unutar kulturnog miljea rimskog helenizma više nije pitanje za diskusiju kad je riječ o ranom kršćanstvu i o kasnome antičkom razdoblju". Ovakva helenizirana kultura u sebi je imala usađene određene ideje i stajališta koja su oblikovala shvaćanje ljudi, njihov govor, način života... drugim riječima... njihovo cjelokupno postojanje. Budući da se "rodilo" u takvoj kulturi, kršćanstvo je na koncu, bilo to dobro ili loše, njome oblikovano. Kršćanstvo se isto tako oblikovalo u debatama sa suvremenim judaizmom glede značaja biblijskih obećanja i tumačenja Staroga zavjeta. Uzeli su zbirku Svetih pisama druge religijske skupine i prisvojili je kao svoju, što je, naravno, dovelo do suprotstavljenih tumačenja - tko je u pravu, a tko nije. ${ }^{4}$ Nadalje, ne smijemo zanemariti ni unutarnje konflikte, koji su doveli do

3 Iako Kaiser ne smatra analogiju vjere egzegetskom metodom niti dijelom egzegetskog procesa.

4 “Židovi i kršćani su se prepirali oko pitanja tko je pravi Izrael. Obje su se religije držale he- 
raznih teoloških debata, zajedno s izvanjskim konfliktima s raznim filozofijama (osobito s gnosticizmom), koje su potekle iz poganstva. Svi ovi prošli i suvremeni čimbenici oblikovali su i formirali oblik te sadržaj patrističke egzegeze.

Posljedica svih čimbenika u ovoj dinamici i izazovnom okruženju bio je rast i razvoj patrističke egzegeze. Kao posljedica takvog pročišćavanja i razvoja, valja obratiti pozornost na dvije stvari: a) razvoj i ulogu regule fidei u patrističkoj egzegezi; b) metodološke pristupe tumačenju Pisma, naime, problematici doslovnog i alegoričnog tumačenja utjelovljenom u antiohijskoj, odnosno aleksandrijskoj školi. Dakle, u ovome dijelu ću članka istražiti razvoj i ulogu regule fidei, služeći se Irinejem kao primarnim primjerom, kao i teološkim pretpostavkama koje su dovele do alegorijskog i doslovnog tumačenja Pisma u patristici.

\subsection{Regula fidei: razvoj i uloga u kontekstu Pisma i predaje}

\subsubsection{Uvod}

Pravilo vjere, odnosno regula fidei, može se shvatiti kao: sažetak glavnih točaka kršćanske vjere, suštinska poruka koju je definiralo Evanđelje i struktura kršćanskog vjerovanja u Boga, prihvaćanje spasenja u Kristu i doživljaj Svetog Duha, sažetu izjavu o ranokršćanskom javnom propovijedanju i zajedničkom vjerovanju, normativni sažetak kerigme (usp. Hartog 2007, 65-66); osnovnu teologiju Crkve, sažetak sadržaja apostolskog učenja u kojem se izražavaju ključne doktrine, kao i rano ustrojavanje apostolske vjere (usp. Bokedal 2013, 234-235); hipotezu o Pismima, osnove kršćanstva (usp. Peckham 2008, 64).

Irinej je bio prvi kršćanski teolog koji je govorio točno o ovoj koncepciji, koja se razvila kao posljedica polemika s gnosticizmom. U tome smislu pravilo vjere bilo je proizvod povijesti i pojavljuje se u dva njegova djela: Against Heresies (I.10.1; I.22.1; III.4.1) i u The Demonstration of the Apostolic Preaching (6. poglavlje). ${ }^{5}$

Međutim, za Irineja "povijesnost" nije značila da je izmislio nešto novo. Tako

brejske, odnosno grčke Biblije i tumačili je, svaka prema svojoj metodi. U njihovim debatama Biblija je uvijek bila u središtu. I dok je usmeni zakon bio jedinstven za Židove, kršćanstvo je svoju jedinstvenost prepoznavalo u vjerovanju u Isusa kao Mesiju i u njegovu milost prema čovječanstvu. U tome kontekstu, svaka religija vraćala se na Bibliju, uvjeravajući onu drugu, vlastite vjernike i poganske promatrače da je upravo ona pravi Izrael" (Hirshman 1996, 22).

5 Primjerice, Irinej u AH I.10.1 piše:... u jednom Bogu, svemogućem Ocu, Tvorcu neba, zemlje, mora i svega što je u njima; i u jednome Kristu Isusu, Božjem Sinu, koji se utjelovio za naše spasenje, i u Svetom Duhu, koji je preko proroka objavio uredbe Božje, i adventima, i rođenju od Djevice, i muci, i uskrsnuću od mrtvih, i uzašašću u nebo u tijelu ljubljenoga Krista Isusa, našega Gospodina, i njegovim budućim objavljenjima s neba u slavi Oca, "da skupi sve stvari u jedno" i uskrsne tijela cijeloga ljudskog roda, kako bi Krist Isus, naš Gospodin, naš Bog, naš Spasitelj i naš Kralj, po volji našega nevidljivog Oca, ... i da izvrši svoj sud nad svima..... 
i Tomas Bokedal $(2013,254)$ opaža da mu pravilo vjere nije predstavljalo neku novinu:

Dapače, ono je uglavnom sredstvo koje Crkvu upućuje na pređašnje formulacije ključnih elemenata kršćanskog vjerovanja, s osobitim isticanjem izvora (Boga, Krista i neprijateljskih apostola) i normativnih elemenata svoje vjere (kristološko i dvograno, odnosno trograno ispovijedanje jedinome Bogu). Pravilo istine ili pravilo vjere kod Irineja odnosi se na samu istinu, odnosno vjeru. Kao takav, cilj mu je izraziti središnje doktrine i rano ustrojstvo apostolske vjere, često u prilično kristaliziranoj formi i redu.

Shodno tomu, Irinej prati pravilo vjere do apostolskog doba tako što usko vezuje kršćansko ispovijedanje vjere, katehetsko učenje, Pismo i rane formulacije vjeroispovijesti. S druge strane, pravilo vjere ima božansko podrijetlo jer Irinej nije dvojio da je pravilo došlo od Boga posredstvom zakona, proroka, Krista, apostola i crkve (usp. Osborn 2003, 147). Na temelju ovih uvodnih bilježaka možemo dublje promotriti neka pitanja povezana s podrijetlom, funkcijom i doprinosom pravila vjere u životu Crkve.

\subsubsection{Kontekst razvoja i krize autoriteta}

Pravilo vjere razvijeno je u kontekstu polemike s gnosticizmom te je u tome smislu "reaktivni" dokument, nastao kao reakcija protiv nečega. Taj je kontekst odredio njegovu formu i sadržaj. I zato, da bismo razumjeli ovaj dokument, moramo razumjeti situaciju s kojom je Irinej bio suočen. Obračunavao se s doktrinom koja je promicala brojne dualizme: teološki dualizam između Boga i demiurga, kristološki dualizam između Krista i Isusa, Logosa i Spasitelja, Krista gore i Krista dolje, soteriološki dualizam koji je nijekao univerzalnost Božje ekonomije spasenja, pisamski dualizam koji je razdvajao Stari od Novog zavjeta uz tvrdnju da Bog Starog zavjeta nije isti Bog kao u Novome zavjetu, eklezijastički dualizam prema kojem se razlikuje obični vjernik od duhovnijeg vjernika, društveni dualizam prema kojem se tvrdi da su neki ljudi po prirodi dobri, a drugi po prirodi loši, praktični dualizam koji se manifestirao u rigorizmu, koji su samo rijetki mogli postići, odnosno u libertinizmu takozvanih superiornih ljudi, i na koncu metafizički dualizam koji je suprotstavljao gornji svijet donjem svijetu te duh i tvar (usp. Vallée 1981, 20-22). Suočen s takvim doktrinama, koje su se u osnovi svodile na razdvajanje, Irinej im se usprotivio drugačijim načinom rada: ujedinjavanjem. Međutim, postavljalo se pitanje na temelju čega, odnosno kojim autoritetom je to učinio?

Ova problematika nije jednostavna jer, kao što Simonetti $(1994,24)$ opaža, gnostici su se služili istom metodom tumačenja kao i Irinej kako bi dali biblijski autoritet svojim učenjima. Budući da Irinej nije imao vlastitih jasnih hermeneutskih načela, bitka se nije vodila oko ispravne egzegetske teorije, nego oko njezina sadržaja. Nadalje, gnostici su se selektivno služili dijelovima Biblije i nadopunja- 
vali ih vlastitim spisima. $U$ isti su mah tvrdili da su mnogi apostolski spisi bili iskvareni ili netočni. Uz to se vodila debata o predaji, gdje je Irinej tvrdio da je Crkva sačuvala istinsku apostolsku predaju. Međutim, gnostici su tvrdili da je njihova usmena predaja očuvala istinsku apostolsku predaju.

U tome kontekstu odlučujući čimbenik, koji odlučuje o tome tko je u pravu a tko ne, nije bilo pozivanje na određenu egzegetsku metodu, Pismo ili predaju, nego, kao što John McRay $(1967,5)$ tvrdi - na apostolstvo:

Glas živih apostola više se nije mogao čuti. Iz samoga stada dižu se glasovi koji preispituju jedinstvo kršćanske vjere i postavljaju se kao autoritet. Nema sustavne teologije pomoću koje bi se suprotstavilo ovim herezama. Nema kanona Pisma koji bi svi priznali kao potpuni i autoritativan, na koji bi se bilo moguće pozvati. Pa, ipak, Irineju je postalo sasvim jasno da se apostoli, koji su utemeljili Crkvu i dali joj doktrinalna učenja, moraju pozvati da bi se oglasili u povodu ovih pitanja.

Logika McRayjeve argumentacije svodi se na to da je Irinej bio među prvima koji su se suočili s pitanjem istinske biblijske egzegeze zbog gnostičkog iskrivljavanja Pisma. On nije imao univerzalno utvrđenu predaju koja bi bila dovoljna za uvjeravanje. Nije imao zatvoreni kanon Pisma na koji bi se mogao pozvati, niti se mogao pozvati na autoritet biskupa (prezbiterska sukcesija), a da prethodno ne pokaže kako se njihov autoritet temelji na apostolskom autoritetu. Stoga, za rješenje ovog konflikta potrebno je pokazati da iza određene predaje, Pisma ili autoriteta biskupa stoji apostolstvo. Tako je mogao argumentirati da su njegova predaja i tumačenje Pisma valjani, a gnostički nisu (usp. McRay 1967, 8-9).

\subsubsection{Odnos predaje i Pisma}

Usko vezano uz pitanje autoriteta jest i pitanje odnosa između predaje i Pisma. Drugim riječima, kompleksnost Irinejeve uporabe Pisma, predaje, apostolstva, prezbiterskog autoriteta itd., neizbježno izbija na površinu pitanjem odnosa između Pisma i predaje. Shodno tomu, moguće je tvrditi da Irinej smatra Pismo podložnim predaji jer predaja čuva i tumači Pismo, čineći Crkvu normom. Ovim se implicira neadekvatnost Pisma. Također, može se reći da je za Irinija Crkva bila primarni autoritet, ali isključivo zato što je očuvala duh obaju zavjeta. Možemo reći da i Pismo i predaja imaju isti autoritet jer je oboje Božja objava i jer se Irinej u svojoj argumentaciji poziva na oboje. Nijedno nije podložno onome drugome jer predaja se ne koristi kao hermeneutičko načelo (usp. McRay 4).

John C. Peckham $(2008,52-56)$ smatra da se kod Irineja predaja paradosis odnosi na prenošenje apostolske doktrine koja je prenesena i očuvana, bilo pisanim ili usmenim putem. Stoga, to ne znači dodavanje izvornoj apostolskoj doktrini niti njezino mijenjanje. Međutim, ako usporedimo broj referiranja na tradiciju i na Pismo, primjerice, u Protiv hereza, glavni argument tiče se Pisma: ondje nalazimo 629 aluzija ili navoda iz Starog zavjeta i 1065 aluzija ili navoda iz 
Novog zavjeta. Paradosis ili predaja spominje se 35 puta: četiri puta odnosi se na gnostičku predaju, jednom na univerzalnu predaju (ne kršćansku), devet puta na predaju starih u Matejevu evanđelju u 15. poglavlju i konačno, 21 na predaju u smislu kršćanske predaje. Shodno tomu, možemo zaključiti da se njegov glavni argument u diskusiji protiv hereza svodi na Pismo. Međutim, ne znači li to da je za Irineja Pismo iznad predaje ili obratno jer on naziva predaju "pravilom istine", "vjerom", "učenjem" i "propovijedanjem". Predaju može tako nazvati jer je sadržaj obojega bio istovjetan zbog činjenice da su potekli od apostola i sadržavali isto apostolsko propovijedanje (Ferguson 2010-, 13). Mitros (1968, 455) opaža da se, unatoč tomu što su na istoj razini po pitanju standarda i norme, Irinej češće poziva na Pismo nego na predaju te je u tome smislu opravdano smatrati Pismo "konačnim uporištem".

\subsubsection{Doprinos pravila vjere životu Crkve}

Pravilo vjere u crkvenoj povijesti pojavio se kao reakcija na određeni te je, u izvjesnom smislu, bio ograničen po pitanju djelokruga i svrhe. Prema Rowanu A. Greeru (1986, 156-157), posredstvom pravila vjere Irinej je Crkvi svoga vremena dao "okvir za tumačenje koji će dovesti do kršćanske transformacije hebrejskih Pisama u koherentan obrazac". Pravilo je pružilo načelo tumačenja, ali u isti su se mah kategorije, koje su usmjeravale tumačenje Pisma, izvlačile iz samoga Pisma.

Iako je pravilo vjere funkcioniralo kao općeniti okvir za tumačenje Pisma, Greer $(1986,176)$ opaža da su, na određenoj razini, mnogi problemi ostali. Kao prvo, dvosmislenost Irenejeve metode tumačenja, jer se koristio tipologijom pomalo alegorično, a ova dvosmislenost najbolje se manifestirala u aleksandrijskom alegorijskom i antiohijskom tipološkom pristupu Pismu. Drugo, o Irinejevoj definiciji Spasitelja, koju nije razriješio, na koncu će se diskutirati na trinitarijanskim i kristološkim diskusijama u stoljećima koja slijede. Treće, Irinej nije govorio mnogo o značenju biblijskog tumačenja za život. Međutim, i Greer (1986, 197199) smatra da je pravilo vjere, u svojoj suštini negativno, a ne pozitivno načelo. Ono je isključivalo netočna tumačenja (sve ono što nije), no nije tražilo točna. Tako jedan odjeljak može imati mnoštvo tumačenja koja su valjana zato što se ne protive pravilu vjere. Iako se time nije riješilo pitanje metode niti pitanja detalja u teološkoj, moralnoj i duhovnoj ekspoziciji Biblije, ograničio se okvir tumačenja, a samim time ograničio se i kontekst unutar kojeg je moguće tražiti značenje. Uz ovaj zaključak, pozabavit ćemo se pitanjem metoda tumačenja Biblije.

\subsection{Doslovna i alegorična metodologija tumačenja: Aleksandrija i Antiohija}

Vidjeli smo da je patristička egzegeza djelomično rezultat pređašnjih utjecaja koji su na razne načine i u različitim mjerama stupili u nju i oblikovali njezinu formu i sadržaj. Međutim, uz to što se gradila na prošlosti, patristička egzegeza u isti se mah razvijala i kao posljedica suvremenih problema, izazova i potreba Crkve. U 
skladu s time, pravilo vjere prije svega je nastalo kao reakcija na gnosticizam, ali nije riješio problem biblijskog tumačenja. Pružio je ograničeni kontekst, odnosno okvir unutar kojeg je moguće tražiti tumačenje, no biblijsko tumačenje i dalje je bilo otvoreno za različite metodologije te, shodno tomu, različite i/ili suprotstavljene teološke zaključke. Među zapaženim primjerima ovakvog razvoja hermeneutike nalaze se takozvana aleksandrijska i antiohijska škola tumačenja, a njih ćemo istražiti u tekstu što slijedi.

\subsubsection{Aleksandrijska škola}

Aleksandrijska škola uglavnom se vezuje za praksu alegorijskog tumačenja s Origenom, kao najpoznatijim predstavnikom ove škole. Ova tradicija tumačenja razvila se kao posljedica kontakta s heleniziranim judaizmom (jedan od tih utjecaja bilo je Filon) i njihove polemike s gnosticima. F. M. Young $(1999,25)$ tvrdi da je rano aleksandrijsko kršćanstvo naginjalo gnosticizmu jer su i Valentin i Bazilid došli iz Aleksandrije, a za razvoj svog sustava služili su se alegorijom. Time se implicira da se nije nužno radilo o prijeporu oko metode, jer i gnostici i aleksandrijski kršćani služili su se istim metodama, nego oko teoloških uvjerenja.

Pod utjecajem Filona, Origen je razvio vlastitu metodu tumačenja. Služio se analogijom tijela, duše i duha, tvrdeći da Pismo nosi tri značenja: doslovno, moralno i duhovno. Priprosti, odnosno neupućeni kršćanin zaustavit će se na spoznaji koja odgovara tijelu Pisma, odnosno njegovu doslovnom značenju. Osoba koja je uznapredovala nahranit će svoju dušu, dok će se oni savršeni uzdići do spoznaje iz duhovnog značenja Pisma. Međutim, Young (2003, 336-337) napominje da se ovakva trostruka klasifikacija značenja Biblije ne odnosi na tri klase vjernika. Točnije, odnosi se na različite faze progresivnog putovanja prema savršenstvu.

Odnos između doslovnog i duhovno-alegoričnog značenja je kompleksan. Prema Origenovu mišljenju, doslovno značenje nije konačni cilj Pisma, nego služi kao polazište za dublje duhovno značenje, koje većina neće vidjeti (usp. Simonetti 1994, 42-43). Origen vidi problematiku doslovnog značenja u dvjema stvarima: u povijesnoj referenci narativa i u prakticiranju pravnih i obrednih propisa. Pripisivao je doslovno tumačenje Židovima, koji su provodili Zakon, tvrdeći da kršćani ne trebaju shvaćati pravne tekstove doslovno, nego duhovno. Također, slikovito shvaća neke od narativa, kao onaj kada Bog sadi drvo poput zemljoradnika ili kad šeta Rajem na ugodnom povjetarcu, čime se naznačuju izvjesni misteriji u nečemu nalik povijesti, a ne u vidu stvarnih događaja. $S$ druge strane, vrlo je doslovno shvaćao neke narative, koje bismo smatrali nemogućima (usp. Young 1999, 25).

Možemo pretpostaviti da se ovakvo duhovno-alegorično značenje koristilo kao žrtveni jarac iz vrlo praktičnih razloga: da bi se eliminirali odjeljci koji isuviše grubo ljudski prezentiraju božanstvo, što je smetalo obrazovanom Grcima i motiviralo gnostike da odbace Stari zavjet. Zbog toga su razni dijelovi Starog zavjeta postali podložni alegoriji: brojevi i etimologije hebrejskih imena, vrijednosni de- 
talji svetih tekstova vezanih uz imena životinja i biljaka itd. (usp. Simonetti 1994, 45-46). Zajednički nazivnik za Origena bilo je njegovo shvaćanje da je u nekim slučajevima doslovno značenje Pisma bilo nejasno uslijed gramatičkih formulacija, raznih retoričkih preokreta ili činjenice da neke riječi mogu imati različita značenja (usp. Kannengiesser 2004, 171).

Ipak, to ne znači da se alegorija koristila bez ikakvih ograničenja. Zato Young $(1999,26)$ opaža da se u Aleksandriji "alegorijsko shvaćanje Pisma temeljilo na dosljednoj metodologiji i koristilo se dosljednim paralelama, pronalaženjem koherentnog niza referenci na nebeske stvarnosti u cijelom Pismu", a Simonetti $(1994,46)$ tvrdi da je Origen bio svjestan rizika od arbitrarnosti, koji je dio takvih procedura, te je nastojao parirati im ističući da je doslovno značenje manjkavo samo u nekim slučajevima, zalažući se za duhovno tumačenje koje će biti povezano s doslovnim značenjem i koje će se potvrditi pomoću drugih biblijskih odjeljaka.

\subsubsection{Antiohijska škola}

Antiohijci su u 4. stoljeću doveli u pitanje alegorijski pristup koji su aleksandrijci prigrlili u 3. stoljeću. Tako možemo smatrati ovu školu reakcijom na aleksandrijsku alegoriju jer je njezina primarna karakteristika bila isticanje doslovnih i povijesnih dimenzija teksta. Zbog toga neki smatraju antiohijce pretečama suvremene povijesne egzegeze (usp. Young 1999, 38).

Opisujući metodologiju tumačenja, Robert C. Hill $(2005,151-152)$ tvrdi da su antiohijci jednostavno inzistirali na tomu da se drevni tekst sagleda onakav kakav jest. Iako su naglašavali doslovno značenje teksta, njihova procedura uglavnom nije bila literalistička niti fundamentalistička. Zato moramo razlikovati doslovno značenje od literalističkog pristupa tekstu: “ono 'doslovno' može uključivati uporabu metafore i drugih stilskih figura, ako je to značenje koje autorova nakana i jezični kontekst sugeriraju", dok će "literalist, s druge strane, biti zadovoljan shvaćanjem izjave ili djela u najdoslovnijem mogućem smislu, bez pokušaja shvaćanja ili pronicanja autorove nakane".

Iako su im zajedničke iste karakteristike, kao što je suprotstavljanje historije (u smislu narativne logike teksta) alegoriji, imali su različite pristupe. Primjerice, Teodor je doveo u pitanje neka tradicionalna proročka i simbolična čitanja te je tumačio proroke i psalme u kontekstu događaja iz povijesti Izraela, a ne kao kriptična proroštva o Mesiji. Za Teodora, alegorija nije bila dopustiva jer je ignorirala historiju, no u nekim slučajevima na temelju historije Pismo opravdava uporabu theorije, odnosno uzvišenijega duhovnog značenja, primjerice u tradicionalnom mesijanskom tumačenju proroštava i psalama, kao i mistično značenje Pjesme nad pjesmama (usp. Hanser \& Watson, 2003, 46; Young 1999, 39). Međutim, u čemu se aleksandrijska alegorija razlikovala od antiohijske theorije?

Prema Youngovu mišljenju $(1999,39)$, alegorija je bila priznata stilska figura 
koju su antiohijci prihvaćali ako je bila indicirana u tekstu. Stoga, alegorija se prije svega tumačila kao stilska figura, a ne kao metoda tumačenja. Preferiralo se doslovno tumačenje, a alegorijsko tumačenje koristilo se jedino onda kad doslovno tumačenje nije bilo moguće (usp. Hanser \& Watson 2003, 46). Time se implicira da za antiohijce problem nije bila sama alegorija, nego hermeneutika koja pogrešno prepoznaje i pogrešno primjenjuje stilske figure.

Konkretno, antiohijci su dopuštali theoriju koja nije produhovljavala biblijska izvješća o stvaranju, Raju, padu u grijeh, pričama iz Evanđelja, uskrsnuću tijela i Božjem kraljevstvu (usp. Young 2003, 346). Ključni događaji u temeljima vjere nisu se smjeli alegorizirati niti produhovljavati jer se to smatralo prijetnjom temeljima vjere. U nastavku ćemo pokušati rekonstruirati temeljne razlike koje se kriju iza konflikta ovih dviju škola.

\subsubsection{Problem rekonstrukcije}

Donald Fairbairn $(2007,1-2)$ opaža da su tijekom 1950-ih patristički teolozi potkopavali model shvaćanja prema kojem se patristička egzegeza dijelila na dvije konkurentne i uglavnom međusobno isključive škole, jedne u Antiohiji i druge, u Aleksandriji. Škola u Antiohiji favorizirala je doslovnu, povijesnu egzegezu, dok je aleksandrijska škola favorizirala alegoričnu egzegezu. Praksa alegoričnog tumačenja pripisuje se platonskom načinu razmišljanja i helenističkim pretpostavkama, dok je antiohijska škola, koja je favorizirala doslovnu, povijesnu egzegezu, bila rezultatom tumačenja Biblije sa stajališta semitske misli.

Fairbairn (2007, 2-3) vidi tri pogrešne pretpostavke u ovome modelu: prva je da su antiohijska i aleksandrijska škola bile unutar sebe vrlo uniformne i jednako zastupljene u ranoj Crkvi, druga je da su aleksandrijski teolozi ${ }^{6}$ bili "negativni” jer su se koristili biblijskim tekstom kao polazištem za svoje filozofske spekulacije, dok su antiohijski teolozi ${ }^{7}$ bili "pozitivci" koji su ozbiljno shvaćali Pismo, i treće: da su različite teologije i homiletički naglasci u Antiohiji i Aleksandriji bili posljedica različitih egzegetskih metoda. On prepoznaje činjenicu da su aleksandrijci nudili figurativna tumačenja brojnih starozavjetnih tekstova koje su antiohijci shvaćali doslovno te da su antiohijci fokusirali svoje učenje i propovijedanje na moralno napredovanje kršćana, dok se aleksandrijsko propovijedanje ponekad čini apstraktnijim i filozofskim u usporedbi s antiohijskim. Međutim, "tvrdnja da su ove razlike bile proizvod potpuno drugačijih egzegetskih metoda pretpostavka je, a ne činjenica”.

6 Klement Aleksandrijski (2/3. stoljeće), Origen (3. stoljeće), Atanazije (4. stoljeće), Didim Aleksandrijski (4. stoljeće) i Ćiril Aleksandrijski (5. stoljeće).

7 Pavao Samosatski (3. stoljeće), Eustahije Antiohijski (4. stoljeće), Diodor iz Tarza (4. stoljeće), Ivan Zlatousti (4/5. stoljeće), Teodor iz Mopsuestije (4/5. stoljeće), Nestor (5. stoljeće), Ivan Antiohijski (5. stoljeće) i Teodoret iz Kira (5. stoljeće). 
Poznati primjer ovoga stava, koji Fairbairn kritizira, jest onaj Rogera E. Olsona (1999, 203-204) koji smatra da su se antiohijski teolozi služili povijesno-doslovnom metodom, dok su se aleksandrijski služili alegorično-duhovnom metodom. Tada je zaključio: "Kako su pristupi ovih dvaju gradova tumačenju Biblije utjecali na njihove kristologije, bit će nam jasnije kad direktnije istražimo ovu temu". Ovim se implicira točno ono što je Fairbairn $(2007,6)$ kritizirao: biblijsko tumačenje pod utjecajem njihove teologije, a ne obratno. Ovakvo je rezoniranje problematično jer, kako Fairbairn smatra, obje su se škole koristile jednakim metodama (doslovno i alegorično tumačenje), i crkveni oci iz istih škola, koji su se navodno služili istom metodom, često bi dolazili do drastično različitih zaključaka. Štoviše, trebamo posvetiti veću pozornost rekonstruiranju kontrolnih teoloških ideja koje su vodile ove dvije škole u svojem biblijskom tumačenju, a ne pripisivati različite teološke ideje njihovim različitim metodologijama tumačenja.

Frances Young $(1999,39$; cf. Hanser \& Watson 2003, 44) tvrdi da se razlike u tumačenju između Aleksandrije i Antiohije nisu nalazile u njihovim egzegetskim metodama, nego poglavito u različitim hermeneutskim metodama: jedna potiče iz retoričkih škola, druga iz filozofskih. Dijelili su jednako uvjerenje da doslovne riječi u biblijskom tekstu upućuju na dublje značenje, ali njihov konflikt odražava višestoljetnu borbu između retoričke i filozofske škole. Obje su se škole držale praksi škola gramatike, retorike i filozofije: to methodikona i to historikona. Ona prva bavila se lingvističkim pitanjima vezanima za tekst: etimologijom riječi, figurativnim govorom i mislima, tropovima i stilom, dok se ova druga bavila pozadinom teksta kako bi objasnila njegov sadržaj i reference koje su u njemu. Međutim, filozofske škole su također isticale ideju da cijeli tekst posjeduje hyponoiju - podsmisao, odnosno dublje značenje. Shodno tomu, gledali su na riječi kao na šifre koje se mogu provaliti i tako otkriti njihovo značenje, umjesto praćenjem njihova redoslijeda u narativnoj argumentaciji. U zaključku, aleksandrijci su isticali to methodikon i filozofske aspekte svojega obrazovanja, dok su antiohijci isticali to historikon te gramatičke i retoričke aspekte. Stoga Young $(2003,352)$ zaključuje: "Razlika nije toliko u egzegetskoj metodi, koliko u hermeneutskim načelima."

Neki će reći da je stvarna razlika između ovih dviju škola u njihovim različitim teološkim pretpostavkama, koje su potom oblikovale njihove metodologije tumačenja i pristupe. Simonetti (1994, 121-126) opaža da se opća patristička hermeneutika razvila u kontekstu debata i kontroverzi, što je dovelo do prihvaćanja izvjesnih doktrina i otpisivanja drugih. Tako se Pismo koristilo za podupiranje određenih stajališta, štoviše često se tekstove vadilo iz konteksta i razmatralo ih se zasebno. Dakle, teologija je, a ne egzgegetske metode niti hermeneutska načela, odgovorna za konflikt između Aleksandrije i Antiohije. Drugim riječima, jednaka egzegetska procedura može dovesti do različitih teoloških zaključaka. Nadalje, budući da Pismo ne predstavlja homogeni doktrinarni korpus, nego tek 
razasute sporadične tragove i indikacije, koje je često teško uskladiti, postaje jasno zašto su se u ranoj Crkvi vrlo kontradiktorne doktrine o istoj temi mogle iznositi uz adekvatnu biblijsku potporu. Premda su suprotstavljene strane u teološkoj debati podupirale svoje doktrine raznim biblijskim odjeljcima, njihovu općenitu orijentiranost uglavnom su određivale općenitije pretpostavke, koje su oblikovale njihovo tumačenje Pisma. Stoga, ove pretpostavke mogu biti rezultat ranijih tradicija, razvoja kontroverzi, općenitog pogleda na biblijske tekstove ili različitih filozofskih polazišta. Na temelju ovoga, Simonetti opaža da antiohijski egzegeti ispoljavaju materijalističku misao, za razliku od antiohijske tendencije produhovljavanja s očitim platonskim podrijetlom.

Slično tomu, Fairbarin $(2007,10-11)$ tvrdi da su različiti pristupi egzegezi proistekli iz različitih načina odbacivanja teološkog izazova arijanizma. Reagirajući na to, antiohijci su tvrdili da onaj koji je trpio i umro nije bio Božji Sin, te su stoga i dalje mogli tvrditi da je Bog Sin neprolazan i jednak Ocu. Takvim kristološkim stajalištem Logos se odvajao od čovjeka Isusa, čime se spasenje shvaćalo kao ljudsko putovanje za Isusom od prvog doba (doba nesavršenstva i smrtnosti) u drugo doba (doba savršenog ljudskog života). Shodno tomu, Stari se zavjet nije čitao kao predslika Novoga, nego kao dokument koji govori o prvome dobu. To je, prirodno, dovelo do naglašavanja povijesnog i doslovnog značenja Starog zavjeta. S druge strane, aleksandrijci su odbacili arijanizam, tvrdeći da je Bog Sin trpio u svojoj ljudskosti, a ne u svojoj božanskoj naravi kao takvoj. Prema njihovu stajalištu o spasenju, sam Bog Logos bio je aktivni sudionik u svim trenucima Isusova života, kako bismo mi mogli biti njegovi dionici. Ipak, razlikovali su ono što je Logos učinio u skladu sa svojom božanskom naravi i ono što je činio u svome novostečenom ljudskom životu. Stoga, smatraju da Stari zavjet upućuje na Krista, tako da je njihovo tumačenje bilo "duhovno", a ne toliko doslovno i povijesno.

Obje strane dijelile su iste ideje: a) jasno razgraničenje između Stvoritelja, stvorenoga i Boga, čime se korjenito nadilaze okolnosti stvorenja; b) Krist je posjedovao i ljudsku i božansku narav (usp. Stang 2012, 533, 541). Međutim, njihovi pogledi na svijet oblikovali su njihove teologije. Govoreći o antiohijskom pristupu Starome zavjetu, Hill $(2005,199-200)$ tvrdi da se iza njihova pristupa Pismu krije osobit pogled na svijet:

U svim ovim područjima misli i života vidimo naglasak na ljudskome - bez nijekanja božanskoga - što kao da ukazuje na stvarnu opasnost od umanjivanja i brisanja. Ljudski autor starozavjetnog teksta i njegova činjenična situacija ne mogu se zanemariti u procesu prelaska - arbitrarnog - u sferu duhovnih značenja; uzvišeno je značenje dopustivo u tekstovima pod uvjetom da se održi njihov kontinuitet s činjenicama; konkretnost izražavanja u opskurnim tekstovima i grubost opisanog ponašanja nužna su implikacija utjelovljenja Riječi u Pismu. 
Isto možemo reći i za aleksandrijski pristup Pismu:

Za Origena, platonista, i stvoreni poredak i biblijski tekst simbolizirali su vječni svijet duhovnih stvarnosti. Simbole i tipologije je shvaćao kao nešto što znači nešto drugo, tako da su riječi Svetoga pisma postale šifra koju treba dešifrirati alegoričnim čitanjem. Dianoia - stvarno značenje - bilo je skriveno jer tako je Duh htio (Young 2003, 351).

U zaključku, možemo reći da je način na koji su ove dvije škole shvaćale kristologiju oblikovao njihovu soteriologiju, njihovo shvaćanje Starog zavjeta i, konačno, njihovu primjenu egzegetskih metoda.

\section{Zaključna razmišljanja: revizija evanđeoske prakse tumačenja Svetog pisma}

Ne možemo okretati kotač povijesti, ali možemo ga proučavati, razmišljati o njemu i nastojati deducirati i primijeniti mudrost prethodnih generacija u situaciji u kojoj se nalazimo. Evanđeosko kršćanstvo uglavnom nema mnogo osjećaja za povijesni razvoj kršćanstva. Vjerojatno nije pretjerano reći da većina evanđeoskih kršćana vjeruje da je, uz iznimku prve Crkve u Novom zavjetu, kršćanstvo počelo njihovom generacijom te da gotovo nitko, uz nekoliko iznimki u povijesti Crkve, nije shvaćao što je kršćanstvo. Međutim, ne možemo pobjeći od činjenice da je naše današnje stanje posljedica povijesnog razvoja. Čak i ona baština koju evanđeoski kršćani najviše cijene - sama Biblija - proizvod je povijesti. Mnoge stvari u koje vjerujemo i koje prakticiramo također su proizvod povijesnog razvoja.

U izvjesnoj mjeri, način na koji evanđeoski kršćani tumače Pismo također je proizvod povijesnog razvoja. Reagirajući na ono što su smatrali zlorabljenjem Pisma u Rimokatoličkoj crkvi, reformatori su nastojali pročistiti crkvenu doktrinu tako što su se pozivali na Pismo, čineći ga jedinim nepogrešivim standardom za kršćansku vjeru i praksu. U svemu tome davali su prostora crkvenoj predaji, ali da bi ona bila prihvaćena, morala je imati temelja u Pismu. Nekoliko stoljeća kasnije, a gradeći na reformacijskoj baštini, većina je evanđeoskih kršćana izgubila svoju povezanost s prošlošću, pretvarajući sola scriptura u solo scriptura. To je dovelo do individualističkog pristupa Bibliji (Isus - Biblija i ja), antitradicionalizma i tradicije slobodnih crkava, što je dovelo do "mnoštva konfliktnih inačica vjere" (usp. Wade 2001). Pitanje je: kako će evanđeosko kršćanstvo ponovno uspostaviti svoju vezu s prošlošću, revidirati svoju doktrinu i prakticirati je bez gubljenja ortodoksije? Povezano $s$ time je i pitanje kako nas razmišljanje o prošlosti može informirati glede naše sadašnjosti.

Odgovori na ova pitanja nisu jednostavni. Naime, situacija odnosa Pisma i predaje u patrističkom razdoblju nije ista kao danas. $\mathrm{U}$ tome smislu, Peckham 
$(2008,70)$ sažima sentiment evanđeoskih vjernika glede Pisma i predaje:

Međutim, postoje velike razlike između situacije u kojoj se nalazio Irinej i današnjice. Nekoliko generacija nakon apostola sasvim je drugačiji kontekst nego 2000 godina distance. Uz tako veliki jaz između nas i samih apostola, najtočniji zapis njihovih učenja nećemo pronaći u ljudima, nego u Svetom pismu. Pomna očuvanost novozavjetnih spisa dobro je potvrđena u akademskim krugovima. Stoga, imam povjerenja da Novi zavjet sadržava točna učenja apostola i njihova učitelja Isusa. Shodno tomu, ne bi bilo potrebe za alternativnim autoritetom koji bi imao ulogu svjedoka ovim spisima, kao što je kod Irineja bio slučaj. Vjerujem da Sveto pismo može govoriti samo za sebe i da su nasljednici apostola oni koji promiču apostolski nauk, što ga nalazimo u Pismu. Tako su sve kršćanske tradicije dužne vraćati se izvornom apostolskom nauku i neprestano iskušavati svoju predaju.

Budući da je predaja kompromitirana, jedino je rješenje učiniti Sveto pismo u isti mah i jedinim nepogrešivim autoritetom i okvirom za tumačenje: pravilom vjere. Rezultat toga pristupa jest "mnoštvo konfliktnih inačica vjere". Međutim, vidjeli smo da je u patrističkoj eri postojao opći teološki okvir - pravilo vjere - koje je omogućavalo brojna valjana tumačenja istog teksta. Danas imamo istu situaciju među evanđeoskim kršćanima. Opći je okvir isti, opća je priča o spasenju ista, ali imamo različite teološke zaključke, tumačenja i praktične primjene raznih teoloških detalja ove velike priče.

Iako je danas za evanđeoske vjernike Pismo jedini nepogrešivi izvor apostolske predaje, više je razloga zbog kojih ne smijemo zanemarivati prošlost: a) učenja crkvenih otaca pružaju nam divan resurs za shvaćanje naše vjere; $b$ ) patristika nas može podsjetiti na središnje istine kršćanstva, što nam danas pruža temelj za procjenjivanje doktrinalnih učenja; c) kad uvidimo što je ono najvažnije, možemo pravilno početi rješavati problem nejedinstva Crkve; d) poznavanje naše prošlosti i baštine pruža nam osjećaj pripadanja nečemu velikome, nečemu što se proteže dalje od vidljivog svijeta (usp. Wade 2001). Dakle, iako ne prihvaćamo sve što se dogodilo tijekom povijesti Crkve, ne smijemo je zbog toga niti potpuno odbaciti.

Konačno, današnji su evanđeoski kršćani, poput Crkve u prvih nekoliko stoljeća i judaizma u Isusovo vrijeme, suočeni s izazovom primjene Pisma u trenutačnoj situaciji: judaizam je razvio brojna pravila i pristupe za to, Isus i pisci Novog zavjeta su to činili, Crkva u prvih nekoliko stoljeća je to činila, kao i protestanti. U tome smislu John L. Thompson $(2013,191)$ govori:

I unatoč uvriježenom vjerovanju da su protestantski tumači prezirali alegoriju, točnije je reći da su prezirali hirovitu alegoriju. I samo Pismo je iziskivalo isuviše slika $\mathrm{i}$ alegorija da bi mogli misliti kako su ovi egzegetski potezi ili strategije potpuno nedopustivi... čak i tada, reformatori su se voljeli smatrati uzorima diskretnosti u svojoj uporabi alegorije, utoliko što njihove alegorije i 
analogije nikad nisu bile hirovite, uvijek su bile sugerirane u samom tekstu i fokusirale su se gotovo isključivo na Krista ili na njegovu Crkvu.

Iako se evanđeoski kršćani deklarativno pridržavaju povijesno-gramatičke metode i promiču je, u praksi, a osobito u njihovim propovijedima, nalazimo brojne primjere alegorija, tipologija, duhovnih analogija itd., vezanih uz Stari i Novi zavjet. Što ćemo sa Starim zavjetom? Možemo li reproducirati egzegetski pristup novozavjetnih autora? Zbog prijašnjih zloporaba, mnogi će odbiti takve pokušaje, dok će drugi reći da imamo jasne smjernice i zaštite kako bismo mogli pronaći Krista u Starom zavjetu, kao što to čini Novi zavjet (usp. Swanson 1996). Posebno je pitanje produhovljavanje i alegorizacija Novog zavjeta koje je odgovorno za nastanak mnoštva novih doktrina među evanđeoskim kršćanima. U svakom slučaju, u pitanju je teška odluka jer, gdje ćemo povući crtu ${ }^{8}$ Problem je u tome što evanđeoski kršćani nemaju izvanjsko pravilo vjere, odbacuju crkveno učiteljstvo, a pozivanje na crkvenu predaju korisno je samo do određene mjere zbog njezine iskvarenosti. Tako nam ostaju dvije mogućnosti.

Možemo beskonačno trčati ukrug ako nastavimo smatrati Bibliju jedinim nepogrešivim izvorom kršćanske doktrine i "prosuditeljem” našega biblijskog tumačenja (pravilom vjere). Međutim, ako imamo dva različita / suprotstavljena tumačenja određene doktrine, koja su potkrijepljena biblijskim argumentima, očito je da je netko u krivu. I opet, tko može odrediti koja je strana pogrešno pristupila Bibliji? Tvrdnja da sama Biblija odlučuje o tome zato što jasno piše o tome (usp. Allert 2004, 342), po mojemu je mišljenju, naivna.

Možda bi bolje mišljenje glasilo: možemo i dalje smatrati Bibliju jedinim nepogrešivim izvorom kršćanske doktrine, nastaviti razvijati svoju povijesno-gramatičku metodu, osobito u pogledu pitanja analogije vjere u egzegetskom procesu (članak H. Waynea Johnsona), ali također biti svjesni da Biblija ne može in toto igrati ulogu pravila vjere, odnosno analogije vjere, kako bi je protestanti nazvali. Nužno je uključiti još nešto. Razlog za to je u činjenici što je prije zaključivanja

8 Primjerice, Graeme Goldsworthy (2001) govori: "Neprepoznavanje jedinstva Pisma navelo je neke među ranim tumačima na pogrešan trag. Dobar primjer za to jest pojava alegorične metode tumačenja u ranoj Crkvi. Budući da se veći dio Starog zavjeta smatrao nekorisnim ili nedovoljno kršćanskim, jedini način da ga se očuva za kršćansku uporabu bilo je prepoznavanje tajnoga "duhovnog" značenja, skrivenog iza prirodnog značenja. Alegorija se činila kao legitimna metoda tumačenja jer ju je kontrolirao sadržaj Novog zavjeta, a kasnije crkvena dogma. Međutim, ono što je nedostajalo bila je kontrola kakvu je Novi zavjet primjenjivao pri čitanju Starog zavjeta. U srednjem vijeku ova je logika odvedena korak dalje. Ne samo što je "nekorisno" prirodno značenje Starog zavjeta dobilo duhovni smisao u Novom zavjetu nego se smatralo da i prirodno značenje Novog zavjeta iziskuje vlastito duhovno tumačenje koje se moglo naći u crkvenoj predaji. Tako je autoritet sada počivao, ne na prirodnom značenju kanona Pisma, nego na učenjima Crkve koja je tumačila duhovno značenje u skladu s vlastitom dogmom." 
kanona Novog zavjeta postojala Crkva, a u početku Crkve postojali su apostoli, a prije njih - Isus. To nešto svakako bi bilo obnova patrističkog razdoblja kao "neke vrste doktrinarnog kanona" (Williams 1999, 139) i razdoblja koje je "za kršćansku vjeru u normativnom smislu temeljno poput nijednog drugog razdoblja crkvene povijesti" (Williams 2006, 24).

Ne želim sugerirati da je sve što je poteklo iz patrističkog razdoblja bilo doktrinarno zdravo i ispravno, niti smatram da ovo nastojanje potkopava doktrinu sola scriptura niti jasnoću Pisma. Naprotiv, otkrivajući ne samo svoje protestantske, nego i katoličke korijene, evanđeoski kršćani mogu samo steći bolji pogled na sutrašnjicu i naučiti vrijedne lekcije.

\section{Literatura}

Allert, Craig D. 2004. What Are We Trying to Conserve?: Evangelicalism and Sola Scriptura. The Evangelical Quarterly 76.4: 327-348.

Armstrong, John H. The Authority of Scripture. The Highway.org. http://www. the highway.com/Sola_Scriptura_Armstrong.html.

Bokedal, Tomas. 2013. The Rule of Faith: Tracing Its Origins. Journal of Theological Interpretation 7/2: 233-255.

Fairbairn, Donald. 2007. Patristic Exegesis and Theology: The Cart and the Horse. Westminster Theological Journal 69/1: 1-19.

Ferguson, Everett. 2003. Backgrounds of Early Christianity. Grand Rapids: Wm. B. Eerdmans Publishing Company.

Goldsworthy, Graeme. 2001. Is the Old Testament for Christians? Monergism. http://www.monergism.com/thethreshold/articles/onsite/otchristians.html

Greer, Rowan A. 1986. Early Biblical Interpretation. Philadelphia: Westminster John Knox Press.

Hanser, Alan J. \& Watson, Duane F. 2003. Introduction and Overview. In: Alan J. Hanser \& Duane F. Watson, eds. A History of Biblical Interpretation. Volume 1, The Ancient Period, 1-54. Grand Rapids: Wm. B. Eerdmans Publishing Company.

Hargis, Jeffrey W. 1999. Against the Christians: The Rise of Early Anti-Christian Polemic. New York: Peter Lang.

Hartog, Paul. 2007. The "Rule of Faith" and Patristic Biblical Exegesis. Trinity Journal Volume 28: 65-86.

Hill, Robert C. 2005. Reading the Old Testament in Antioch. Leiden: Brill.

Hirshman, Marc. 1996. A Rivalry of Genius Jewish and Christian Biblical Interpretation in Late Antiquity. Albany: State University of New York Press. 
Johnson, Wayne H. 1988. The "Analogy of Faifh" and Exegetical Methodology: A Preliminary Discussion on Relationships. Journal of the Evangelical Theological Society 31/1: 69-70.

Kaiser, Walter. 1982. Evangelical Hermeneutics: Restatement, Advance or Retreat from the Reformation. Concordia Theological Quarterly 46/2-3: 167-180.

Kaiser, Walter. 1985. The Uses of the Old Testament in the New. Chicago: Moody Press.

Kaiser, Walter. 1990. Hermeneutics and the Theological Task. Trinity Journal 12:3-14.

Kannengiesser, Charles. 2004. Handbook of Patristic Exegesis: The Bible in Ancient Christianity. Leiden: Brill.

Mathison, Keith. 2001. The Shape of Sola Scriptura. Moscow: Canon Press.

McGrath, Alister E. 2001. Reformation Thought: An Introduction. Oxford: Blackwell Publishing.

McRay, John. 1967. Scripture and Tradition in Irenaeus. Restoration Quarterly 10/1: 1-11.

Mitros, Joseph F. 1968. The Norm of Faith in the patristic Age. Theological Studies 29/3: 444-471.

Osborn, Eric. 2003. Irenaeus of Lyons. Cambridge: Cambridge University Press.

Peckham, John C. 2008. Epistemological Authority In The Polemic Of Irenaeus. Didaskalia 19/1: 51-70.

Schaff, Philip. 2007. The Creeds of Christendom: History of the Creeds, Volume I, Part I. New York: Cosimo Publications.

Simonetti, Manilo. 1994. Biblical Interpretation in the Early Church. Edinburgh: T\&T Clark.

Stang, Charles M. 2012. The Two 'I's of Christ: Revisiting the Christological Controversy. Anglican Theological Review 94/3: 529-547.

Swanson, Scott A. 1996. Can We Reproduce The Exegesis Of The New Testament? Why Are We Still Asking? Trinity Journal 17/1: 67-76.

Thompson, John L. 2013. At the Margins of the Rule of Faith: Reflections on the Reception History of Problematic Texts and Themes. Journal of Theological Interpretation 7/2: 187-198.

Vallée, Gérard. 1981. A study in anti-Gnostic polemics: Irenaeus, Hippolytus, and Epiphanius. Waterloo: Wilfrid Laurier University Press.

Wade, Rick. 2001. Introduction: Evangelicals and Tradition. Probe Ministries. https://www.probe.org/scripture-and-tradition-in-the-early-church/.

Williams, Daniel H. 1999. Retrieving the Tradition and Renewing Evangelicalism: 
A Primer for Suspicious Protestants. Grand Rapids: Wm. B. Eerdmans Publishing Company.

Williams, Daniel H. 2006. Tradition, Scripture, and Interpretation: A Sourcebook of the Ancient Church. Grand Rapids: Baker Academic.

Young, F. M. 1999. “Antiochene School”. In: John H. Hayes, ed. Dictionary of Biblical Interpretation, 38-40. Abingdon Press. Nashville.

Young, F. M. 1999. “Alexandrian School." In: John H. Hayes, ed. Dictionary of Biblical Interpretation, 25-26. Abingdon Press. Nashville.

Preveo s engleskog Davor Edelinski

Ervin Budiselić

\title{
Lessons from the Early Church for Today's Evangelical Christianity
}

\begin{abstract}
Presuming that within Evangelical Christianity there is a crisis of biblical interpretation, this article seeks to address the issue, especially since Evangelicals view the existence of the church as closely connected to the proclamation of the Truth. Starting with a position that Evangelical hermeneutics is not born in a vacuum, but is the result of a historical process, the first part of the article introduces the problem of sola and solo scriptura, pointing out some problematic issues that need to be addressed. In the second part, the article discusses patristic hermeneutics, especially: a) the relationship between Scripture and tradition embodied in regula fidei and; b) theological presuppositions which gave birth to allegorical and literal interpretations of Scripture in Alexandria and Antioch. In the last part of the article, based on lessons from the patristic era, certain revisions of the Evangelical practice of the interpretation of Scripture are suggested. Particularly, Evangelicals may continue to hold the Bible as the single infallible source for Christian doctrine, continue to develop the historical-grammatical method particularly in respect to the issue of the analogy of faith in exegetical process, but also must recognize that the Bible cannot in toto play the role of the rule of faith or the analogy of faith. Something else must also come into play, and that "something" would definitely be the recovery of the patristic period "as a kind of doctrinal canon."
\end{abstract}

